\title{
Antibacterial and Antagonistic Activity of Selected Traditional Medicinal Plants and Herbs from East Wollega Zone against Clinical Isolated Human Pathogens
}

\author{
Tamirat Tesfaye Ayele ${ }^{1^{\star}}$, Melkamu Biyana Regasa $^{1}$ and Desalegn Amenu Delesa ${ }^{2}$ \\ 1Department of Chemistry, College of Natural and Computational Sciences, Wollega University, \\ P.O. Box: 395, Nekemte, Ethiopia \\ ${ }^{2}$ Department of Biology, College of Natural and Computational Sciences, Wollega University, \\ P.O. Box: 395, Nekemte, Ethiopia
}

\begin{abstract}
Traditional medicinal plants and herbs are used by the communities of western Ethiopia including Wollega administrative zones; although in most cases no scientific studies have been done to prove the efficacy of these medicinal plants. To provide evidencebased data for traditional medicinal plants which are very important heritages and used by our community at large, research based screening is very important. Therefore, in this study laboratory based assessment of medicinal plants commonly used by the order of traditional practitioners in east Wollega administrative zone was carried out. Nine plants samples were collected from different areas of east Wollega administrative zone of and were analyzed for their antimicrobial activities. The diethyl ether and methanol extracts of some medicinal plants have inhibited bacterial strains; Streptococcus pyogenes, Streptococcus pneumonia, Streptococcus agalacticeae, Salmonella tphyrium, with minimum inhibition concentration of $25 \%(25 \mathrm{mg} / \mathrm{mL})$ of the stock solution $(100 \mathrm{mg} / \mathrm{mL})$. S.pneumonia was found to be the most susceptible bacteria for the methanol extract of the root of Ricinus communis with inhibition zones of $20 \mathrm{~mm}$ and MIC of $25 \mathrm{mg} / \mathrm{mL}$. However; S.tphyrium was the most resistant to all extracts of the selected plants with no inhibition zone. The methanol extracts of all plants were most potent while the diethyl ether extracts of all medicinal plants were ineffective against all bacterial strains. As such, it can be concluded that Ricinus communis had shown antibacterial activity having potential for further study followed by Millettia ferugunea to serve as source of antibacterial agents in the future.
\end{abstract}

Copyright@2015 STAR Journal, Wollega University. All Rights Reserved.
Article Information Article History:

Received : 12-05-2015

Revised : 13-09-2015

Accepted : 18-09-2015

Keywords:

Traditional medicinal plants

Pathogens

Antibacterial activity

East Wollega Zone

Minimum inhibition concentration

*Corresponding Author:

Tamirat Tesfaye Ayele

E-mail:

tamrattesfaye2641@gmail.com

\section{INTRODUCTION}

Traditional medicines are the basis for the modern drug discovery. An enormous variety of medicinal plants are used worldwide by about $80 \%$ of the world population, although in most cases no scientific studies have been done to prove the efficacy of these medicinal plants. And also plants have a long history of use on the African continent for the treatment of different diseases and complaints. In certain African countries, up to $90 \%$ of the population still relies exclusively on plants as a source of medicines (Watt et al., 1962; Dalziel, 1956; Sofowora, 1982; Oliver-Never, 1986; Kerharo et al., 1974). Plantderived substances have recently become of great interest owing to their versatile applications. Medicinal plants are the richest bio-resource of drugs of traditional systems of medicine, modern medicines, nutraceuticals, food supplements, folk medicines, pharmaceutical intermediates and chemical entities for synthetic drugs (Ncube et al., 2008).
However, so far only two of the major 18 agroecological zones defined as hot to warm humid lowlands and Tepid to cool humid midlands carry out some research and production activities of some herbs, spices and related aromatic plants in Ethiopia. The research made so far on Ethiopian medicinal plants has been mostly of producing inventories and checklists. Ethiopian traditional life is painted with the hallmark of widespread use of traditional medicinal plants with various levels of sophistication within the indigenous medicinal lore. It is blended with religious thinking and various beliefs and need further investigation. The basic categories of practitioners also are difficult to define. Ethiopians people have their own set of written and or oral pharmacopoeias with the medicinal use of some species being restricted to each ethnic group. The cultural and indigenous knowledge of medicinal plants in Ethiopia is unevenly distributed among each community members. Peoples in different zones/location with different religious, linguistic 
Tamirat Tesfaye Ayele et al.,

and cultural backgrounds have their own specific knowledge about use of plants which in part has gradually entered wide circulation in the country (Dawit et al., 1993; Gelahun et al., 1989). This knowledge is important and applicable to our times for various reasons. Firstly, it promotes the discovery of new alternatives to drugs currently being used. Secondly, it is important from a conservation point of view; if over exploitation of a medicinal plant species should occur, restrictive measures can and should be taken to ensure survival and sustainability of the specific species. From a cultural point of view, important knowledge regarding the traditional use of plants is lost as it is not being passed on from one generation to the next anymore. Thus it is important that this knowledge be documented to ensure that it is at the disposal of future generations who may benefit from it (Thring et al., 2006).

It is believed that most of the people living in east Wollega zone rely on plant derived medicines to address their health care needs. Consultation of traditional healers and the use of herbal medicine provided by them play an integral role in rural healthcare, with the majority of the rural population consulting traditional healers to address most, if not all, of their healthcare needs. This is mainly due to the high cost of Western medical care in the country, the inaccessibility of facilities rendering modern Western medical care to rural communities, unavailability of novel drugs and the cultural role that the use of traditional medicines play in these communities. Whereas modern Western medical treatment aims to treat the immediate physiological processes and symptoms of a disease condition, traditional healers aim to restore balance and a general sense of well being of a patient on both a mental and physiological level. For this reason a combination of plants are usually prescribed to patients by traditional healers, who believe that the synergistic or additive effects of the correct combination of plants will be more successful in treating a patient than would be a single drug. So the recent research attempted on investigating antibacterial activity of traditional medicinal plants selected from east Wollega administrational zone and their antagonistic activity against clinical isolated human pathogens.

\section{MATERIAL AND METHODS}

\section{Collection of Medicinal Plants}

In order to identify biologically active herbs and plants sampling is the first important step. For this study, preidentified plants by the local practitioners were collected from the various parts of the plants and herbs from east Wollega administrative zone using standard procedures. The voucher specimens of these plants were prepared and identified by the National Herbarium, Department of Biology, Wollega University. The collected plants were washed with water to remove the soil and dust particles. Then they were dried in thoroughly shaded place, and blended to form a fine powder and stored in airtight containers. The whole plant or parts of plants and herbs were used to prepare extracts for the study.

\section{Human Pathogenic Bacteria Species}

Human pathogenic bacteria such as Streptococcus pyogenes, Streptococcus pneumoniae, Salmonella typhrium, Streptococcus agalateae, were obtained from Ethiopian Public Health Institute (EPHI), Addis Ababa, and were maintained in Nutrient agar slant at $4^{\circ} \mathrm{C}$ and used for further experimental studies.
Sci. Technol. Arts Res. J., July-Sep 2015, 4(3): 175-179

\section{Plant Extracts Preparation}

The pulverized (coarsely powdered) plant and herb materials were placed in a separator funnel with diethyl ether and allowed to stand at room temperature for a period of at least three days with frequent agitation until the soluble matter has dissolved. The marc remaining after diethyl ether extraction was allowed to dry and then extracted by maceration (with occasional shaking) using $99 \%$ methanol as menstruum. The mixture for each solvent then was strained, the marc (the damp solid material) was pressed, and the combined liquids were clarified by filtration. The miscella was concentrated by use of a rotator vapor (Buchi, model R-144, Switzerland) at temperature between $40-45^{\circ} \mathrm{C}$. The dried extracts were weighed, transferred into vials and then stored at $4^{0} \mathrm{C}$ for antibacterial analysis use.

\section{Preparation of Sterile Disc}

Whatman's No.3 filter paper was punched into $6 \mathrm{~mm}$ disc form and they sterilized, each sterile disc was incorporated individually with $50-100 \mu$ l of extracts using micropipette. Precautions were taken to prevent the flow of the solvent extract from the discs to the outer surface.

\section{Inoculums Preparation}

Inoculums were prepared by mixing a few microbial colonies $(1 \mathrm{ml})$ from exponential phase with $9 \mathrm{ml}$ of sterile peptone water and compared the turbidity with that of the standard $0.5 \mathrm{McF}$ arland solution which is equivalent to $10^{6}-10^{8} \mathrm{cfu} / \mathrm{mL}$ (Cirillo et al., 1998)

\section{Antimicrobial Activity Assay}

Agar disc diffusion method was used to determine the antimicrobial activity of plant extracts as described by Jayaraman et al. (2008); Kumara et al. (2009); Apgar et al. (2005). The $20 \mathrm{ml}$ Muller-Hinton Agar (MHA) were poured into Petri plates and allowed to solidify and dry. The sterile swab was dipped into the properly adjusted inoculums and the excess was removed by gentle rotation of the cotton swab against the surface of the tube. The test microorganisms were uniformly swabbed on the Mueller Hinton Agar (MHA) using the cotton swab. The inoculated plates were left at room temperature for 3-5 minutes to allow for any surface moisture to be absorbed before applying the extract. Each piece of sterile 6-mm assay discs impregnated with each plant extract, tetracycline or erythromycin (for bacteria as positive control), sterile distilled water and standard solution as negative control were applied on the MHA and left at room temperature for $1 \mathrm{hr}$ to let the extract and controls diffuse to the agar and incubated at $37^{\circ} \mathrm{C}$ for $24 \mathrm{~h}$ for each bacterium (Arzese et al., 2000). All tests were performed in triplicate and zone of inhibition were measured from the edge of each disc after the incubation period by using sliding calipers and ruler (Baquero et al., 1991).

\section{RESULTS}

\section{Background Information of the Medicinal Plants}

The selected medicinal plants from East Wollega were subjected to study for their biological activity against disease causing bacteria. The communities under the study areas were used traditional medicinal plants and herbs to treat different aliments/diseases by following the prescription given from the traditional healers. The plants and herbs collected for this purpose were summarized their traditional use in Table 1. The name of the selected plants and herbs were written in the local language afan oromo $(\mathrm{O})$ and scientific name. 
Table 1: Plants used for treatment of common diseases with single-species prescription in East Wollega

\begin{tabular}{|c|c|c|c|c|c|c|c|c|}
\hline No & $\begin{array}{l}\text { Local } \\
\text { Name } \\
\text { Oromo }\end{array}$ & $\begin{array}{l}\text { Scientific } \\
\text { Name }\end{array}$ & Family & $\begin{array}{l}\text { Habit } \\
\text { (site of } \\
\text { growth) }\end{array}$ & $\begin{array}{l}\text { Plant } \\
\text { parts } \\
\text { used }\end{array}$ & Indigenous use & Method of preparation & $\begin{array}{l}\text { Route of } \\
\text { Admini- } \\
\text { stration }\end{array}$ \\
\hline 1 & Edda fitie & $\begin{array}{c}\text { Clematis } \\
\text { longicauda } \\
\text { steud ex.A. rich }\end{array}$ & Ranunculaceae & $\begin{array}{l}\text { Climber } \\
\text { (wild) }\end{array}$ & Leaf & Tonsillitis & $\begin{array}{l}\text { juice of freshly } \\
\text { squeezed leaf is mixed } \\
\text { with melted butter }\end{array}$ & Oral \\
\hline 2 & Korxobi & $\begin{array}{c}\text { Plantago } \\
\text { lanceolata L. }\end{array}$ & Plantaginaceae & $\begin{array}{l}\text { Herb } \\
\text { (wild) }\end{array}$ & whole & $\begin{array}{l}\text { Herpes } \\
\text { wounds }\end{array}$ & $\begin{array}{l}\text { The juice of freshly } \\
\text { squeezed leaf is } \\
\text { pasted with butter and } \\
\text { made to ointment. }\end{array}$ & Topical \\
\hline 3 & Kabosimbiro & $\begin{array}{c}\text { Ricinus } \\
\text { communis L. }\end{array}$ & Euphorbiacea & $\begin{array}{c}\text { Shrub } \\
\text { (domestic) }\end{array}$ & Root & Rabies & $\begin{array}{c}\text { The root is pounded, } \\
\text { well spiced, and mixed } \\
\text { with food. }\end{array}$ & Oral \\
\hline 4 & Agamsa & $\begin{array}{c}\text { Carissa } \\
\text { edulis Vahl. }\end{array}$ & Apocynaceae & $\begin{array}{l}\text { Shrub } \\
\text { (wild) }\end{array}$ & Root & Rabies & $\begin{array}{l}\text { The root is powdered } \\
\text { and mixed with food. }\end{array}$ & Oral \\
\hline 5 & Komogno & $\begin{array}{c}\text { Brucea } \\
\text { antidysenterica } \\
\text { J.F. Miller }\end{array}$ & Simaroubiaceae & $\begin{array}{l}\text { Shrub } \\
\text { (wild) }\end{array}$ & Root & Toothache & $\begin{array}{l}\text { The root is chewed or } \\
\text { held between teeth. }\end{array}$ & $\begin{array}{c}\text { (Buccal) } \\
\text { topical }\end{array}$ \\
\hline 6 & Dhangago & $\begin{array}{c}\text { Rumex } \\
\text { abyssinicus } \\
\text { Jacq. }\end{array}$ & Ploygonaceae & $\begin{array}{l}\text { Herb } \\
\text { (wild) }\end{array}$ & Root & Gonorrhea & $\begin{array}{l}\text { The root is powdered } \\
\text { and mixed with honey. }\end{array}$ & Oral \\
\hline 7 & Dhumuga & $\begin{array}{c}\text { Justicia } \\
\text { schimperiana } \\
\text { (Hochest. Ex } \\
\text { Nees) T. } \\
\text { Anders } \\
\end{array}$ & Acanthaceae & $\begin{array}{c}\text { Shrub } \\
\text { (domestic) }\end{array}$ & Root & Seizure & $\begin{array}{l}\text { The root is dried, } \\
\text { pounded, and pasted } \\
\text { with butter and put over } \\
\text { head. }\end{array}$ & Topical \\
\hline \multirow[b]{2}{*}{8} & \multirow[b]{2}{*}{ Sotalloo } & \multirow{2}{*}{$\begin{array}{l}\text { Millettia } \\
\text { ferruginea } \\
\text { (hochst.) } \\
\text { Baker. }\end{array}$} & \multirow[b]{2}{*}{ Fabaceae } & \multirow[b]{2}{*}{$\begin{array}{l}\text { Tree } \\
\text { (wild) }\end{array}$} & Bark & Tooth-ache & $\begin{array}{l}\text { The bark is chewed or } \\
\text { held between teeth. }\end{array}$ & $\begin{array}{c}\text { (buccal) } \\
\text { topical } \\
\end{array}$ \\
\hline & & & & & Root & Gangrene & $\begin{array}{l}\text { The powdered root is } \\
\text { mixed with rancid butter } \\
\text { or dispersed in } \\
\text { perforated area. }\end{array}$ & $\begin{array}{l}\text { Oral/ } \\
\text { topical }\end{array}$ \\
\hline 9 & Mata bokke & $\begin{array}{l}\text { Echinops } \\
\text { Iongisetus } \\
\text { A.Rich. }\end{array}$ & Asteraceae & $\begin{array}{l}\text { Shrub } \\
\text { (wild) }\end{array}$ & Root & $\begin{array}{c}\text { Migraine, } \\
\text { diarrhea, heart } \\
\text { pain, different } \\
\text { forms of infections }\end{array}$ & $\begin{array}{l}\text { The root is powdered } \\
\text { and mixed with meal } \\
\text { and oral taken or } \\
\text { applied on external } \\
\text { surfaces infected. }\end{array}$ & $\begin{array}{l}\text { Oral/ } \\
\text { topical }\end{array}$ \\
\hline
\end{tabular}

\section{Antibiotic Activity Assay}

As depicted in the table 2 and 3, the effectiveness of antibiotics was determined against each bacterial strain (S.pneumonia, S.agalacticeae, S.pyogenes, S. tphyrium).
Tetracycline was showed the highest inhibition zone against S.agalacticeae $(30 \mathrm{~mm})$ while both Tetracycline and Erythromycin did not show any inhibition against S.pyogenes.

Table 2: Antimicrobial activity of methanol extracts and antibiotic against some human pathogenic bacteria at $100 \mathrm{mg} / \mathrm{mL}$

\begin{tabular}{|c|c|c|c|c|c|}
\hline \multirow{2}{*}{ Test plants/antibiotics } & \multirow{2}{*}{ Solvent } & \multicolumn{4}{|c|}{ Zone of inhibition } \\
\hline & & S.pneumonia & S.agalacticeae & S.pyogenes & S.tphyrium \\
\hline Clematis longicenda(leaf) & Methanol & $\star * *$ & $* * *$ & $\star \star *$ & $* * *$ \\
\hline Stephanie abssinica(leaf) & Methanol & *** & $* * *$ & *** & $* * *$ \\
\hline Plantago lanceolata(whole) & Methanol & $* * *$ & $* * *$ & *** & *** \\
\hline Ricinus communis (root) & Methanol & $20 \mathrm{~mm}$ & $10 \mathrm{~mm}$ & *** & *** \\
\hline Carissa edulis(root) & Methanol & $9 \mathrm{~mm}$ & $* * *$ & *** & *** \\
\hline Brucea antidyscenatrica(root & Methanol & $7 \mathrm{~mm}$ & *** & $* * *$ & $* * *$ \\
\hline Brucea antidyscenatrica(bark) & Methanol & $8 \mathrm{~mm}$ & *** & *** & *** \\
\hline Rumex absinicus(root) & Methanol & $* * *$ & *** & *** & *** \\
\hline Justicia schnimperriana(root) & Methanol & *** & *** & *** & *** \\
\hline Millettia ferugunea(root) & Methanol & $* * *$ & *** & $10 \mathrm{~mm}$ & *** \\
\hline Millettia ferugunea(bark & Methanol & $10 \mathrm{~mm}$ & $\star * *$ & $10 \mathrm{~mm}$ & $* * *$ \\
\hline Tetracycline & & $8 \mathrm{~mm}$ & $30 \mathrm{~mm}$ & $\star * *$ & $20 \mathrm{~mm}$ \\
\hline Erythromycin & & $15 \mathrm{~mm}$ & $15 \mathrm{~mm}$ & $* * *$ & $10 \mathrm{~mm}$ \\
\hline
\end{tabular}

\section{Antibacterial Activity of the Plant Extracts}

Diethyl ether and methanol extracts of the root, bark, leaf and whole of nine plants were investigated for their biological activities. The methanol extracts of eight plants out of nine showed moderate to strong inhibitory activity against stock cultures of $S$. pyogenes, S.pneumonia, S.tphyrium and $S$. agalacticeae. Plant samples like Plantago lanceolata (whole), Rumex absinicus (root), and Justicia schnimperriana (root) did not show any biological activities against all clinical isolates for methanol extracts.
The diethyl ether extracts of Plantago lanceolata (whole), Carrisa edulis (root), Brucea antidyscenatrica (bark), Millettia ferugunea (bark) have inhibited bacterial strains S. pyogenes, and S.tphyrium. Ricinus communis (root) showed high inhibiting power against the growth of $S$. pneumonia $(20 \mathrm{~mm})$ and $S$. agalacticeae $(10 \mathrm{~mm})$ in methanol extract while no inhibition activity was observed for diethyl ether extract of it. The plant was used for treating rabbies by the traditional healers which need further investigation. In addition, the plant indicates that it has maximum inhibiting ability like the standard 
antibiotics. In other words, it has a promising potential for drug development and related activities. Carissa edulis (root) methanol extract showed moderate inhibition zone with $9 \mathrm{~mm}$ against S.pneumonia.

Table 3: Antimicrobial activity of diethyl ether extracts against some human pathogenic bacteria at $100 \mathrm{mg} / \mathrm{mL}$

\begin{tabular}{|c|c|c|c|c|c|}
\hline \multirow{2}{*}{ Test plants/antibiotics } & \multirow{2}{*}{ Solvent } & \multicolumn{4}{|c|}{ Zone of inhibition } \\
\hline & & S. pneumonia & S. agalacticeae & S. pyogenes & S. tphyrium \\
\hline Clematis longicenda(leaf) & Diethyl Ether & *** & *** & $* * *$ & $* * *$ \\
\hline Stephanie abssinica(leaf) & Diethyl Ether & *** & *** & *** & $* * *$ \\
\hline Plantago lanceolata(whole) & Diethyl Ether & $* * *$ & *** & $* * *$ & $* * *$ \\
\hline Ricinus communis (root) & Diethyl Ether & *** & *** & $* * *$ & *** \\
\hline Carissa edulis(root) & Diethyl Ether & *** & *** & $* * *$ & *** \\
\hline Brucea antidyscenatrica(root & Diethyl Ether & *** & *** & $* * *$ & *** \\
\hline Brucea antidyscenatrica(bark) & Diethyl Ether & *** & *** & $7 \mathrm{~mm}$ & $* * *$ \\
\hline Rumex absinicus(root) & Diethyl Ether & $* * *$ & *** & $* * *$ & $* * *$ \\
\hline Justicia schnimperriana(root) & Diethyl Ether & $* * *$ & *** & *** & $* * *$ \\
\hline Millettia ferugunea(root) & Diethyl Ether & *** & *** & ** & *** \\
\hline Millettia ferugunea(bark & Diethyl Ether & $* * *$ & $* * *$ & $* * *$ & $* * *$ \\
\hline Tetracycline & & $8 \mathrm{~mm}$ & $30 \mathrm{~mm}$ & *** & $20 \mathrm{~mm}$ \\
\hline Erythromycin & & $15 \mathrm{~mm}$ & $15 \mathrm{~mm}$ & $* * *$ & $10 \mathrm{~mm}$ \\
\hline
\end{tabular}

Brucea antidyscenatrica (root and bark) of methanol extract showed medium antibacterial activity against S.pneumonia with $7 \mathrm{~mm}$ and $8 \mathrm{~mm}$ respectively. The diethyl ether extract of its bark showed $7 \mathrm{~mm}$ inhibition zone against S.pyogenes strains. This result indicates that the plant is rich in biologically active compounds which can be function at high concentration.

Justicia schnimperriana (root) and Rumex absinicus (root) showed no inhibition against all bacterial strains used in this study for the two solvents involved in the extraction process. However, the community uses it to treat gonorrhea and seizure disease without evidence of healing potential of it.

Millettia ferugunea (root) methanol extract was moderately reactive against S.pyogenes strain while it was not active against all strains used in this study. The positive result against gram-positive bacteria (S.pyogenes) indicated that the plant is constituted with compounds which act as an inhibitor of these bacteria species. The methanol and diethyl ether extracts of bark of this plant showed significant inhibition activity against gram-positive bacteria such as S.pneumonia and S.pyogenes and also gram-negative bacteria like S.tphyrium. This implies that the bark of this plant extract contains broad spectrum compounds of natural origin. Hence, further study is suggested to identify and characterize these biological active compounds since the community uses this plant for treating toothache and gangrene. The MIC value of plant extracts against the tested bacteria ranged as serial dilution $100 \%(100$ $\mathrm{mg} / \mathrm{mL}), 50 \%(50 \mathrm{mg} / \mathrm{mL}), 25 \%(25 \mathrm{mg} / \mathrm{mL})$ and $12.5 \%$ $(12.5 \mathrm{mg} / \mathrm{mL})$ (methanol and diethyl ether) extracts were observed. The most frequent MIC value of the extracts was $25 \%$ of the extract $(25 \mathrm{mg} / \mathrm{mL})$.

\section{DISCUSSION}

Now days, many naturally occurring compounds found in plants, herbs, and spices have been shown to possess antimicrobial functions and serve as a source of antimicrobial agents against pathogens (Shahwar et al., 2009; Cheruiyot et al., 2009; Ganjewala et al., 2009; Doughari, 2006; Doughari et al., 2007). Bacterial infectious diseases represent an important cause of morbidity and mortality worldwide. development of new antimicrobial agents for treatment of bacterial infections is of increasing interest. Different medicinal plants are widely used in Western Ethiopia for the treatment of various diseases and illness.

Most tested plant extracts showed antibacterial activity against bacterial strain which may reflect the antibacterial activity of plant active ingredients that inhibit bacterial growth. Antimicrobial activity was recorded when the zone of inhibition is greater than $5 \mathrm{~mm}$. The antimicrobial activity profile of all species of plants and herbs against the tested strains indicated that S.tphyrium was the most resistance bacterium of the entire bacterial test strains and did not observe any inhibition zone at all. Similarly, S.agalacticeae was found to be the second most resistance bacteria. In contracts, some strains were mostly become sensitive to different plants species.

In general, among the tested bacterial strains, streptococcus was found to be more sensitive to many of the test agents than others. The antibacterial activity was more pronounced on the gram-positive bacteria (streptococcus species) than the gram-negative bacteria The reason for the difference in sensitivity between grampositive and gram-negative bacteria might be ascribed to the differences in morphological constitutions between these microorganisms, gram-negative bacteria having an outer phospholipidic membrane carrying the structural lipopolysaccharide components. This makes the cell wall impermeable to antimicrobial chemical substances. The gram-positive bacteria on the other hand are more susceptible having only an outer peptidoglycan layer which is not an effective permeability barrier. Therefore, the cell walls of gram negative organisms are more complex in lay out than the gram positive ones acting as a diffusion barrier and making them less susceptible to the antimicrobial agents than are gram positive bacteria (Bland et al., 2001). In spite of this permeability differences, however, some of the extracts have still exerted some degree of inhibition against gram-negative organisms as well.

Several reports by McDonald et al (1997) have indicated that infectious skin disorders are very common in Ethiopia. Thus, the fact that all species of the tested plants showed activity against streptococcus species 
Tamirat Tesfaye Ayele et al.,

might justify the extensive use of these agents for the treatment of human infections.

Findings of this study show that these plants exhibited various sizes of inhibition zones with different solvents against the bacteria they were tested on. However; this difference cannot be used as a model to draw any conclusions because the amount of active ingredients per extract is not the same. Therefore all the plant extracts which showed any activity were considered to have positive activity while those with no activity at all were considered to have negative activity. Thus, in this study gram-positive bacteria were found to have more susceptibility as compared to gram-negative bacteria species. This is in line with earlier studies which also owe this observed to the differences in chemical composition and structure of cell wall of both types of microorganisms (Nostro et al., 2000; Hodges, 2002).

\section{CONCLUSIONS}

The study has been able to establish and document the important medicinal plants against clinically isolated human pathogens. The study has also demonstrated significant antibacterial activity in some of these plants especially in their diethyl ether and methanol extracts. This study has further confirmed that these plants contain the phytochemical which have healing properties according to previous reports. However; in this study we did not isolate the active compounds responsible for antibacterial activity since clinical trials and toxicity studies were also not carried out. Therefore further research should be carried out on these and once it is done it will serve as lead compounds in the manufacture of novel drugs which farmers can also use as one of the approaches in prevention and control of diseases. This could also be an important health and economic resource.

\section{Conflict of Interest}

Conflict of interest none declared.

\section{Acknowledgements}

The authors are thankful to Ethiopia Public Health Institute (EPHI) for providing human pathogens and Wollega University for providing finance for this project.

\section{REFERENCES}

Apgar, B., Greenberg, G. and Yen, G. (2005). Prevention of group $B$ streptococcal disease in the newborn. American Family Physician 71: 903-910.

Arzese, A.R., Tomasetig, L. and Botta, G.A. (2000). Detection of tet $Q$ and ermF antibiotic resistance genes in Prevotella and Porphyromonas isolates from clinical specimens and resident microbiota of humans. Journal of Antimicrobial Chemotherapy 45:577-582.

Baquero, F., Martinez-Beltran, J. and Loza, E. (1991). A review of antibiotic resistance patterns of Streptococcus pneumoniae in Europe. Journal of Antimicrobial Chemotherapy 28 (Suppl. C):31-83.

Bland, M., Vermillion, S., Soper, D. and Austin, M. (2001). Antibiotic resistance patterns of group $B$ streptococci in late third-trimester rectovaginal cultures. American Journal of Obstetrics and Gynecology 184:1125-1126.

Cheruiyot, K.R., Olila, D., Katerega, J., (2009). In-vitro antibacterial activity of selected medicinal plants from Longisa region of Bomet District, Kenya. African Healthy Sciences 9: 42-46.
Sci. Technol. Arts Res. J., July-Sep 2015, 4(3): 175-179

Cirillo, D.M., Valdivia, R.H., Monack, D.M. and Falkow, S. (1998). Macrophagedependent nduction of the Salmonella pathogenicity island 2 type III ecretion system and its role in intracellular survival. Molecular Microbiology 30: 175-178.

Dalziel, J.M. (1956). Useful Plants of West Tropical Africa. Crown Agents for Overseas Government: London.

Dawit Abebe and Ahadu Ayehu. (1993). Medicinal plants and enigmatic health practices of northern Ethiopia, BSPE, Addis Ababa.

Doughari, J.H, (2006).Antimicrobial activity of Tamarindus Indica Linn. Tropical Journal of Pharmaceutical Research 5: 597-603.

Doughari, J.H., Pukuma, M.S.S., De, N., (2007). Antibacterial effects of Balanites aegyptiaca L. And Moringa oleifara Lam on Salmonella typhi. African Jounal of Biotechnology 6: $2212-2215$

Ganjewala, D., Silviya, S., Kishwar, H.K., (2009). Biochemical Compositions and antibacterial activities of Lantana camara Plants with Yellow, Levender, red and white flowers. Journal of Biosciences 3: 69-77.

Gelahun Abate and Etse Debdabe. (1989). Ethiopian traditional medicine (in Amharic), Pp 244.

Hodges, N. (2002). Pharmaceutical Applications of Microbiological Techniques, In: Pharmaceutics, The Science of Dosage Form Design, $2^{\text {nd }}$ Edition, Aulton, M. E. (Editor), Harcourt Publishers Limited, London, p. 606.

Jayaraman. S, Manoharan. M.S and Illanchezian. S (2008). In-vitro Antimicrobial and Antitumor Activities of Stevia Rebaudiana (Asteraceae) Leaf Extracts. Tropical Journal of Pharmaceutical Research 7(4): 1143-1149

Kerharo, J., Adam, J.G. (1974). La Pharmacopée Sénégalaise Traditionelle, Vigot Frères: Paris.

Kumara, M., Agarwala, R., Deyb, K., Raib, V., Johnsonc, B. (2009). Antimicrobial Activity of Aqueous Extract of Terminalia chebula Retz. on Gram positive and Gram negative Microorganisms. International Journal of Current Pharmaceutical Research 1(1): 56-60.

McDonald, C. L.,. Kuehnert, M.J., Tenover, F.C. and Jarvis, W.R. (1997). Vancomycin-resistant enterococci outside the health-care setting: Prevalence, sources, and public health implications. Emerging Infectious Disease 3(3): 311-317.

Ncube, N.S., Afolayan, A.J., Okoh, A.I.(2008). Assessment techniques of antimicrobial properties of natural compounds of plant origin: current methods and future trends. African Journal of Biotechnology 7(12):1797-1806.

Nostro, A., Germano, M.P., D'Angelo, V., Marino, A. and Cannatelli, M.A. (2000). Extraction Methods and Bioautography for Evaluation of Medicinal Plant Antimicrobial Activity. Letters in Applied Microbiology 30: 379-384.

Oliver-Bever, B. (1986). Medicinal Plants in Tropical West Africa, Cambridge University Press: Cambridge.

Shahwar, D., and Raza, M.A. (2009). In-vitro antibacterial activity of extracts of Mimusops elengi against gram positive and gram negative bacteria. African Journal of Microbiology Research 3(8):458-462

Sofowora, A. (1982). Medicinal Plants and Traditional Medicine in Africa, John Wiley: Chichester.

Thring, T.S.A. and Weitz, F.M. (2006). Medicinal plant use in the Bredasdorp/Elim region of the Southern Overberg in the Western Cape Province of South Africa (Electronic version). Journal of Ethnopharmacology 103: 261-275.

Watt, J.M., Breyer-Brandwijk, M.G. (1962). Medicinal and Poisonous Plants of Southern and Eastern Africa. $2^{\text {nd }}$ Edition, Published by $\mathrm{E}$ and S Livingstone: Edinburgh. 